\title{
Somatostatin Receptor Type 5
}

National Cancer Institute

\section{Source}

National Cancer Institute. Somatostatin Receptor Type 5. NCI Thesaurus. Code C17927.

Somatostatin receptor type 5 (364 aa, $\sim 39 \mathrm{kDa}$ ) is encoded by the human SST R5 gene.

This protein is involved in somatostatin-dependent $\mathrm{G}$ protein-coupled receptor signaling. 